\title{
Exploring Cultural Psychology: Introduction to a Book Forum on Towards Cultural Psychology of Religion: Principles, Approaches, Applications by Jacob A. Belzen
}

\author{
Lewis R. Rambo ${ }^{1}$
}

Published online: 17 March 2017

(C) Springer Science+Business Media New York 2017

\begin{abstract}
This article introduces a book forum on Jacob A. Belzen's book Towards Cultural Psychology of Religion: Principles, Approaches, Applications. The introduction discusses the relatively recent "turn to culture" and how it has affected the field of psychology of religion and the variety of concerns examined by the journal Pastoral Psychology.
\end{abstract}

Keywords Jacob Belzen C Culture · Psychology of religion · Cultural psychology of religion

Over the last two decades, we have experienced a "turn to culture" due to our growing awareness of diversity around the world, the fast-paced changes brought on via rapid globalization, the massive communications expansion, and the relocation of millions of immigrants and refugees. Recognizing the often profound differences in cultures and understanding the importance of these differences and the impact of multiple cultural options, scholars and many others have sought to engage culture as a pervasive and powerful force in our world as well as within individuals and communities.

I have participated in this growing awareness of diversity around the world because I have had the good fortune to spend extended periods of time in China, Germany, Israel, Japan, and Korea. My goal during most of these times spent living outside the United States was to do research on the nature of converting. My original work on conversion was rooted in the 1970s approach to psychology of religion. Without fully recognizing it at the time (1971-1975), however, at the University of Chicago I was laying the foundation for an interdisciplinary and cultural approach to my future research. During my $\mathrm{PhD}$ program at the University of Chicago, I took courses with Salvatore Maddi (the psychology of meaning), Victor Lidz (sociology of religion), Victor Turner (anthropology), and Talcott Parsons (sociology of religion).Working with Don Browning as my dissertation advisor, I studied William James in depth. A few years

Lewis R. Rambo

lewisrayrambo@yahoo.com

1 San Francisco Theological Seminary, San Anselmo, CA, USA 
later, when I began to focus my research on conversion, I quickly sought to go beyond psychology. I began to explore the disciplines of anthropology and sociology, and I found that scholars in these fields were blazing a trail to a new understanding the complex nature of religious transformations in many different contexts - many different cultures.

During the 1980s I spent sabbaticals in Japan, Korea, and Israel. In these extraordinary places, I met all kinds of converts: Jews who became Christians, Buddhists who became Christians, Christians who became Jews. While teaching at San Francisco Theological Seminary and the Graduate Theological Union, Berkeley, I was involved with the Center for New Religious Movements (under the brilliant leadership of Jacob Needleman). I interviewed and conducted participant-observation research with members of groups such as the Unification Church (better known as the "Moonies") and the International Church of Christ in San Francisco.

One of the most important influences on my work, especially my work on the cultural dimensions of religion and conversion, came about through my working with Asian $\mathrm{PhD}$ students at the Graduate Theological Union. These brilliant and diligent students became immersed in the program in religion and psychological studies, and they challenged me to recognize the Western bias in the field of psychology. When they delved into contemporary American psychology, they soon realized that American psychology was influenced by Western values, methods, and theories. How, they would ask, can American psychology fully comprehend the nature of Korean culture, personhood, relationships, etc.? I was at first very captivated by Western psychology, but I gradually grasped that psychology in the United States (and perhaps the United Kingdom, Germany, etc.) was infused with Western culture.

My dissertation students helped me to reframe my confusion with the limitations of psychology in relation to understanding the fundamental importance of culture. I experienced a breakthrough (some might even call it an intellectual "conversion"). ${ }^{1}$ One of the most important dimensions of conversion that had largely been ignored by conversion scholars (especially psychologists) is the cultural matrix in which converting is nurtured and shaped. The religious converting process takes different forms in different contexts.

From the 1990s until now, more and more scholars of conversion have seriously considered the cultural aspects of transformative experiences and processes. ${ }^{2}$ I was fortunate to meet Jacob Belzen at a 2008 conference in Seoul, Korea, sponsored by the Korean Association for Christian Counseling and Psychotherapy. One of the organizers was Dr. Soo-Young Kwon. The speakers included Nalini Arles (India), Jacob Belzen (the Netherlands), Archie Smith, Jr. (United States), Aart van Beek (United States and the Netherlands), and myself, Lewis Rambo (United States).

In the years since that conference, Jacob Belzen and I have corresponded frequently. He is a warm and compassionate friend. He continues to dazzle me with his wide and deep scholarship (which he shares with humility and generosity). It is an honor for this journal to publish this book forum.

\footnotetext{
${ }^{1}$ I am grateful for being challenged by the following brilliant $\mathrm{PhD}$ students I have worked with over the years: Kyu Yun Duk, Bitna Kim, Hak Soon Im, Soo-Young Kwon, Hee Cheol Lee, Peter Sam Nguyen, Shinhwan Pan, and Chizuko Saito.

${ }^{2}$ For those interested in the cultural dimensions of counseling and psychotherapy, see this journal's 2002 book forum on Cultural Psychotherapy: Working with Culture in the Clinical Encounter by Karen M. Seeley (2000, Pastoral Psychology, 51(1), 41-86. For a broad overview of the nature of cultural psychology, see the 2007 book forum on Indigenous and Cultural Psychology: Understanding People in Context edited by Uichol Kim, KuoShu Yang, and Kwang-Kuo Hwang (2006, Pastoral Psychology, 56, 53-119).
} 
Now, to the content of the book that is the subject of the following book forum.

There are several ways to read Towards Cultural Psychology of Religion. One can read the book as a marvelous and rich overview of the development of the field of psychology (especially in Europe), the psychology of religion, and, more recently, the cultural psychology of religion. Readers will be richly rewarded by Belzen's panoramic and detailed recounting and assessment of the work of German psychologists (especially Wilhelm Wundt) and of the development of these fields in the Netherlands and the United States. Another way to read the book is to savor it as if you were having a long conversation with a brilliant, articulate, and charming scholar who has invited you into his study. The conversations, of course, may take place over several days or weeks.

The central question of the book is, what is culture? How does it influence persons, religions, and society? We use the term constantly, but we rarely step back and ask ourselves how we define and understand the meaning(s) of culture. Culture is a complex, interconnected, and at times conflicting tapestry of proscriptions and prescriptions for behavior, attitudes, values, etc. Culture includes language, art, music, customs, gender expectations, food, religion, politics, artifacts, symbols, ethics, and ethoses. Joan Laird (1998) provides a helpful and robust description of culture that focuses on the impact of cultural processes on all of us. According to Laird, culture is dynamic, fluid, and emergent; it is performative and improvisational. She asserts that "we 'perform' our cultural stories of gender, ethnicity, race, and so on as we move through the days in time and space. Furthermore, each performance, each enacted storying, is both unique and at the same time located in and related to the larger social discourses of meaning from which we gather narrative threads, symbols, and ritual possibilities - a combination of tradition and imagination" (p. 24).

Jacob Belzen, professor at the University of Amsterdam, is one of the most prolific, erudite, and creative psychologists of religion in the world. ${ }^{3}$ In his book Towards Cultural Psychology of Religion, Belzen (2010b) identifies the distinctiveness of cultural psychology as its emphasis on the pervasive and powerful impact of culture on humans: "Whereas contemporary psychology generally recognizes that not only human interactions are influenced by culture, but that also individuals' feelings, thinking, experiences and behavior are shaped by it: cultural psychology conceives of these as being inherently cultural - as being the result of human embeddedness in culture, which is therefore to be considered as a genuine element of all human functioning relevant for psychology" (p. 38).

Furthermore, Belzen (2010b) states that

. . . cultural psychology does not search inside the human being to investigate belief, feeling, reasoning and behavior, but rather tries to understand how the specific form of life the person is embedded in, constitutes, and structures feelings, thoughts and conduct. Cultural psychologists try to counterbalance the prevailing bias in psychology according to which psychological phenomena have their origin in the intra-individual processes. They stress that psychological phenomena — such as attitudes, emotions, motives, perceptual outlook, forms of reasoning, memory and so on - are not just shaped by a surrounding culture, but are constituted by and rooted in particular cultural interactions. (pp. 60-61)

\footnotetext{
${ }^{3}$ For more information about Professor Belzen, see Prof. Dr. J. A. (Jacob) van Belzen, University of Amsterdam, http://www.uva.nl/en/about-the-uva/organisation/staff-members/item/j.a.van-belzen.html?page=10 \&pageSize $=50$. See also Kelly Bulkeley's article on Belzen's international series in the psychology of religion (Bulkeley 2005).
} 
In Towards Cultural Psychology of Religion, Belzen is modest in his goals; he does not see his book as a comprehensive textbook on cultural psychology of religion or as a finished product exemplifying an ideal vision of the emerging field. Rather, he provides 12 fascinating chapters in which he addresses profound issues regarding the foundations of psychology in general and of psychology of religion in particular. Each chapter critically examines the history of the emergence of psychology and the vicissitudes of how psychology has explored the nature of religion in its many facets. Each chapter also offers case studies of different approaches to the psychology of religion, especially history- and phenomenology-based projects.

Belzen's book challenges us to plumb the depths of our own cultural influences and examine how these can both distort and deepen our understanding of other cultures, encouraging us to candidly acknowledge our own cultural limitations and be open to learning very different approaches to the discipline of psychology and our understanding of the nature of various religions. ${ }^{4}$ Genuine cultural engagement with "the Other" can be fascinating but also disconcerting and disorienting. Nevertheless, once we begin to comprehend the degree to which our own culture shapes our values, perceptions, and even feelings, we can gain a deeper appreciation of different cultural perspectives and honestly face the limitations and contradictions of our own culture. Towards Cultural Psychology of Religion provides us with questions, methods, and a guidebook for our own journey into the marvelous but at times complex waters of culture in all its variety and strangeness.

Belzen's book Towards Cultural Psychology of Religion has stimulated intense interest and vigorous debate since it was published in $2010 .^{5}$ For this book forum, we are fortunate to have the following scholars join the discussion by addressing Belzen's provocative and informative book from diverse perspectives: Aart van Beek; Michael Carroll; co-authors Al Dueck, Jeffrey Ansloos, Austin Johnson, and Christin Fort; and Edênio Valle.

Aart van Beek was born and raised in the Netherlands. He earned a ThD from the South Asia Graduate School of Theology in Singapore and a DMin degree from the Claremont School of Theology. He has also lived and worked in Indonesia for many years, serving as a missionary and teaching pastoral counseling at various theological schools, including Jakarta Theological Seminar in Indonesia. He is currently the pastor of the Parkview Presbyterian Church in Sacramento, California. Van Beek has published widely. His book Cross-Cultural Counseling (Fortress Press) is especially relevant to this book forum.

Michael P. Carroll is a professor of sociology at Wilfrid Laurier University of Waterloo, Ontario, Canada. His main research interest is the sociology of religion, and he has published several monographs on popular Catholicism in different national contexts (including Italy, Ireland, and northern New Mexico) over various historical periods.

\footnotetext{
${ }^{4}$ Belzen does not offer his own definition of religion; he is probably wise to avoid this particular ongoing debate. Psychologists of religion, however, would profit from definitional discussions about religions. One of the best books on this topic is religion scholar Thomas A. Tweed's (2006) nuanced and insightful book Crossing and Dwelling: A Theory of Religion. Martin Riesebrodt's (2010) The Promise of Salvation: A Theory of Religion provides a fascinating and compelling argument from the perspective of a sociologist of religion.

${ }^{5}$ See the special issue of the journal Mental Health, Religion and Culture-13(4), 327-410, published in 2010which contains ten articles by a wide range of psychologists of religion. These papers provide a fascinating look at the predicament of contemporary psychology of religion through the lens of culture. Others reject Belzen's emphasis on the importance of history, phenomenology, and the central place of culture in comprehending both religion and persons. Belzen (2010a) response paper, "To Read and To Be Read-The Problematic Nature of Communication: Comment on Comments," is both informative and illustrative of the conflicts and conundrums in the fields of psychology and the cultural psychology of religion.
} 
Edênio Valle has been teaching psychology of religion since 1978 in the Graduate Program in Religious Studies of the Pontifical Catholic University of São Paulo/Brazil. He is now professor emeritus of the same university. After his theological studies at the Theologische Hochschule St. Augustin (Bonn, Germany), he completed doctoral studies in psychology at the Pontifical Salesian University (Rome, Italy). He was the first president of the National Association for Religious Studies. He is a member of the ANPPEP (National Association for Research and Postgraduate Studies in Psychology/Division of Psychology and Religion). He is the founder of the Psychotherapeutic Institute for Religious (ITA) in São Paulo, Brazil. Valle has published many books and articles in scientific journals. He translated Belzen's Towards Cultural Psychology of Religion into Portuguese.

Al Dueck is a Canadian whose parents were German Ukrainian Mennonites. Al and his wife were active members of the African American Mennonite fellowship in Boone, North Carolina, while Al completed his MA in counseling at Appalachian State University and pastored churches in the fellowship. He completed his doctoral studies at Stanford University in psychology. He is currently Distinguished Professor of Cultural Psychologies at the Fuller School of Psychology. Dueck is the author of Between Jerusalem and Athens: Ethical Perspectives on Culture, Religion, and Psychotherapy and, with Kevin Reimer, A Peaceable Psychology: Christian Therapy in a World of Many Cultures.

Jeffrey Ansloos is a graduate of the Fuller School of Psychology and is presently a faculty member in the Department of Child and Youth Welfare at the University of Victoria, British Columbia, Canada. As a member of the Fisher River Cree Nation, his research interest focus is on Indigenous perspectives on nonviolence, human rights, mental health, peace-building, and restorative justice.

Austin Johnson is a doctoral student in the clinical psychology program at the Fuller School of Psychology. He has completed a master's degree in anthropology, and his dissertation research is focused on existentialism as an integrative lens for psychology, anthropology, and theology. He hails from Texas, which he claims is a culture of its own.

Christin Fort is a completing her clinical internship as a doctoral candidate in the Fuller School of Psychology. Her research interests emerge from her African American heritage and are focused on the intersection of attachment theory, intersubjective systems theory, and divine passability.

\section{References}

Belzen, J. A. (2010a). To read and to be read-The problematic nature of communication: Comment on comments. Mental Health, Religion \& Culture, 13(4), 417-436.

Belzen, J. A. (2010b). Towards cultural psychology of religion: Principles, approaches, applications. New York: Springer.

Bulkeley, K. (2005). Revival movement: Jacob Belzen's international series in the psychology of religion. Religious Studies Review, 31, 141-145.

Kim, U., Yang, K. S., \& Hwang, K. K. (Eds.). (2006). Indigenous and cultural psychology: Understanding people in context. New York: Springer.

Laird, J. (1998). Theorizing culture: Narrative ideas and practice principles. In M. McGoldrick (Ed.), Re-visioning family therapy: Race, culture, and gender in clinical practice (pp. 20-36). New York: Guilford Press.

Riesebrodt, M. (2010). The promise of salvation: A theory of religion (trans: Rendall, S.). Chicago: University of Chicago Press.

Seeley, K. M. (2000). Cultural psychotherapy: Working with culture in the clinical encounter. Northvale: Jason Aronson.

Tweed, T. A. (2006). Crossing and dwelling: A theory of religion. Cambridge: Harvard University Press. 